\title{
Relation of severe eosinophilia and microfilariasis to chronic African endomyocardial fibrosis
}

\author{
J J ANDY, F F BISHARA, O O SOYINKA
}

From the Department of Medicine and Mental Health, Faculty of Health Sciences, University of Ife, Ile-Ife, Nigeria

SUMMARY Over a two-year period, 44 patients had an eosinophil count above the 97 th centile. Thirteen of these 44 had heart disease presenting within six months of the onset of symptoms. Microfilariasis was the most likely cause of the raised total eosinophil in these 13 patients. In all, the raised eosinophil count was returned to normal by the use of diethylcarbamazine (Banocide). Eleven of the 13 were followed up and eight of them (73\%) developed clinical features of cardiac constriction and tricuspid regurgitation. The mean duration of follow-up was two years. Limited cardiac catheterisation studies in six of the patients showed evidence of constriction or of tricuspid regurgitation. The clinical features of these eight patients were indistinguishable from those found in chronic endomyocardial fibrosis. This disease was further suggested by recurrent cerebral embolism in one, and a large pericardial effusion in another; and it was also present in the one patient to come to necropsy. Thus, microfilaria-induced eosinophilia, when high, is frequently associated with heart disease which appears to be chronic endomyocardial fibrosis many months after the eosinophilia has returned to normal.

A group of diseases in which chronic and severe eosinophilia is a prominent feature, namely Löffler's eosinophilic parietal endocarditis, eosinophilic leukaemia, and "eosinophilic collagen vascular disease" are known to be associated with endomyocardial damage. ${ }^{1}$ In addition diseases associated with transient hypereosinophilia such as eosinophilic leukaemoid reaction, ${ }^{2}$ Löffler's eosinophilic pneumonia, ${ }^{3}$ trichinosis, ${ }^{45}$ and filariasis ${ }^{6}$ are sometimes associated with endomyocardial damage.

In the tropical rain forest belt of Africa, endomyocardial fibrosis is common. It occurs mainly between the ages of 25 and 35 years, and accounts for 10 to 15 per cent of cardiac disease in Uganda 78 and for 21 per cent of acquired heart disease in Nigerian children. ${ }^{9}$ This fibrosis of the endomyocardium, which is usually most severe in the inflow and apical portions of one or both ventricles, but which usually spares the outflow tracts, is, in general, indistinguishable from the lesion that occurs in eosinophilic heart diseases. ${ }^{1} 10$

Eosinophilia is conspicuous only in a few indigenous African patients with endomyocardial fibrosis. Some European residents in Africa have been known to develop an endomyocardial fibrosis-like disease, and a severe degree of eosinophilia occurred in

Received for publication 28 August 1980 almost all of them. ${ }^{11}$ In some of these European patients eosinophilia reverted to normal, either spontaneously, 12 or as a result of treatment with hydrocortisone ${ }^{13}$ or antiparasitic agents. ${ }^{14}$ It has been suggested that endomyocardial fibrosis is the "burnt-out" phase of an eosinophilic heart disease, ${ }^{1}$ and microfilariasis has been postulated as the cause of the raised eosinophil count in endomyocardial fibrosis. ${ }^{6}{ }^{15}$ Initial attempts in Nigeria, however, to establish a relation between eosinophilia and chronic African endomyocardial fibrosis ${ }^{15}$ were not supported when the observations were extended. ${ }^{16}$ From Uganda, a study on 15 well-established cases of endomyocardial fibrosis also failed to establish any association between eosinophilia and chronic endomyocardial fibrosis. ${ }^{17}$ But assuming that the cardiac damage in endomyocardial fibrosis is triggered by parasite-induced eosinophilia, a raised eosinophil count need not be present in chronic endomyocardial fibrosis, since it is well known that such eosinophilia tends to run a selflimiting course. The distinctive features of the early stage of African endomyocardial fibrosis are not described and thus diagnosis is not made. Further, some of the Europeans who developed endomyocardial fibrosis while resident in Africa might have had Löffler's parietal endocarditis which appears to be a disease that predominantly affects 672 
European men in the fourth or fifth decade. ${ }^{118}$

An increase in eosinophil count caused by parasitic diseases is common in tropical Africa. The present study was undertaken to establish whether or not this is associated with heart disease and how such disease evolves.

\section{Subjects and methods}

Two hospitals in Ife and two in Ilesha, in Oyo State of Nigeria, were included in the study. In one of the hospitals in Ilesha (The Wesley Guild Hospital) total eosinophil counts were frequently performed to help in the diagnosis of parasitic infestations, especially microfilariasis which is perhaps the most frequent cause of severe eosinophilia in this locality. All total eosinophil counts in this study were performed in this hospital. Since eosinophilia seen in our locality was not usually chronic, we reasoned that if it was associated with heart disease, its level would be higher at the onset of that heart disease than when the disease was in a chronic phase. Additionally we decided that because eosinophilia was very common, any association with heart disease could best be assessed by seeking very high levels of eosinophil counts and early in the course of heart disease. Therefore a preliminary analysis of Wesley Guild data was undertaken, and it was established that total eosinophil counts of $3000 / \mathrm{mm}^{3}$ or over were above the 97th centile in our locality. Total eosinophil counts were then studied over a two year period on all patients below the age of 20 who presented with heart failure of less than six months duration, the aetiology of which could not be ascribed to hypertension, rheumatic heart disease, coronary disease, a congenital lesion, cor pulmonale, pericardial disease, anaemia, or any other known form of heart disease. The age of 20 was selected as an arbitrary cut-off point to limit the chances of previous subclinical cardiac damage from any cause. If the total eosinophil count was $2500 / \mathrm{mm}^{3}$ or greater, it was repeated, and if the average of two counts was $3000 / \mathrm{mm}^{3}$, or greater the patient was selected for further tests and observation. As controls, randomly selected patients with rheumatic heart disease, sickle cell disease, the nephrotic syndrome, hypertensive heart disease, and chronic right-sided endomyocardial fibrosis, and patients with microfilaria in the peripheral blood, had total eosinophil counts performed on two occasions, and the average of the two results recorded. In addition during the two years, the total eosinophil count was performed on a large number of clinically diagnosed cases of microfilariasis, with or without filariasis in the blood, and on patients with intestinal parasites diagnosed on microscopy. The patients with hyper- eosinophilia and with the recent onset of heart disease had the following examinations carried out: a chest $x$-ray, with left lateral, 12 lead electrocardiogram, urinalysis and microscopy, stool examination for ova and parasites, serum electrolytes and urea, a haematocrit, and a white blood count. A thick blood film was examined for microfilariasis on at least three occasions and a skin snip examination was performed. In the last seven cases, the Knott's concentracion as well as the filtration technique for microfilaria diagnosis were also used.

The cardiac patients were closely followed as out patients. Defaulters were traced and brought back for study. Right heart catheterisation via a right antecubital vein cut-down and using a No. 7 Cournand's catheter was carried out in five of the patients undergoing prolonged follow-up who developed clinical features of cardiac constriction. Left heart catheterisation using the Seldinger technique and a pig-tail catheter, and a right heart catheterisation were also performed in a sixth such patient. Only pressures were measured.

The following clinical and radiological features were taken as indicative of cardiac constriction usually seen in endomyocardial fibrosis: gross ascites with minimal leg oedema, conspicuously distended neck veins with proptosis, and cardiomegaly with relatively oligaemic and clear lung fields. In addition clinical tricuspid regurgitation was diagnosed by the presence of a typical regurgitant murmur with inspiratory accentuation along the lower sternal border, or by the presence of a prominent systolic pulsation of an enlarged liver with or without the typical murmur, or by the presence of a regurgitant $\mathrm{V}$ wave in the distended neck veins.

\section{Results}

The distribution of total eosinophil counts in our laboratory during the two year period is shown in Table 1. Of 1956 patients who had total eosinophil estimations, 44 had levels greater than the 97th centile, and 13 of these $44(29.5 \%)$ had recently developed heart disease. They comprised 12 boys and one girl, and their ages ranged between 6 and 18 (mean 12.5) years. The distribution of total eosinophil counts in the control patients is shown in

Table 1 Total eosinophil count in our laboratory

\begin{tabular}{lcc}
\hline Eosinophil $\left(\mathrm{mm}^{3}\right)$ & No. of cases & $\%$ of total \\
\hline ₹ 980 & 1581 & $80 \cdot 8$ \\
$1000-1980$ & 244 & $12 \cdot 5$ \\
$2000-2980$ & 87 & $4 \cdot 4$ \\
> 3000 & 44 & $2 \cdot 2$ \\
Total & 1956 & $100 \%$ \\
\hline
\end{tabular}


Table 2. The presenting signs and symptoms in the patients with heart disease are summarised in Table 3. Fever was an early feature in all the patients. This fever was low grade, and occurred mostly during the afternoons; it was observed for a few days in all three patients who presented within 10 days of onset of their symptoms. Transient and itchy urticarialtype skin rash was complained of by five patients, but was observed in one patient during his hospital stay. One patient (case 3) described a giant urticarial rash (Calabar swelling) affecting an ankle and a forearm at the onset of his illness.

Table 2 Levels of total eosinophil counts in different patients

\begin{tabular}{llc}
\hline Condition & No. of patients & Mean and $S E^{\star}$ \\
\hline Sickle cell disease & 28 & $598 \pm 100$ \\
Rheumatic heart disease & 14 & $610 \pm 168$ \\
Hypertensive heart disease & 20 & $598 \pm 119$ \\
Nephrotic syndrome & 13 & $958 \pm 347$ \\
Chronic right-sided & & $1082 \pm 221$ \\
$\quad$ endomyocardial fibrosis & 13 & $1482 \pm 122$ \\
Microfilariasis & 22 & \\
\hline
\end{tabular}

$\star \mathrm{SE}=$ standard error.

Two patients presented with signs of meningitis and semi-coma. Their cerebrospinal fluid showed a normal cell count, sugar, and pressure, but the protein was slightly raised in one. Both made a complete neurological recovery. Two patients had pericardial-type chest pain. Facial puffiness and periorbital swelling was generally worse in the early morning. The total eosinophil count, white blood cell levels, and results of examinations for microfilaria are also shown in Table 3. Administration of diethylcarbamazine (Banocide) returned the total eosinophil count to normal, that is less than $500 / \mathrm{mm}^{3}$ in all the patients. Table 4 shows the close similarities between electro- cardiographic findings in these patients and those reported for cases of chronic endomyocardial fibrosis. ${ }^{9}$ 19-23 The cardiac silhouettes on chest radiograph were dominated by right. sided (particularly right atrial) dilatation (Fig. 1c).

\section{PROGRESSION OF DISEASE}

One patient (case 13) died at home within two months of discharge from hospital and another was lost to follow-up. Eight of the remaining 11 patients $(73 \%)$ developed features of right-sided constriction with tricuspid regurgitation, during a mean follow-up period of 24 months (Fig. 1a). One of them (case 4) had a huge chronic pericardial effusion from which $500 \mathrm{ml}$ transudate was aspirated (Fig. 1b). The initial ascites presenting in six patients disappeared readily on treatment, but a chronic ascites, more resistant to treatment, reappeared within six to 18 months in three of them.

At right heart catheterisation the right atrium was very dilated in all the six patients studied and except in one (case 5), it proved impossible to manipulate the catheter into the right ventricle. The mean right atrial pressure was raised in all six patients. Two types of atrial pressure curves were recorded: (a) an M-shaped pattern with deep " $y$ " and sometimes deep " $y$ " and " $x$ " troughs (Fig. 2) and (b) a regurgitant "V" wave (Fig. 3). In the only patient in whom ventricular and pulmonary pressures were recorded, the right ventricular tracing showed a dip and plateau pattern (Fig. 3) typical of the pressure contour in restrictive heart disease. In addition, the mean wedge pressure, the right ventricular enddiastolic pressure, and the mean atrial pressure in this particular patient were almost identical $(11,11$, and $10 \mathrm{mmHg}$, respectively) which also suggests restriction (Fig. 2). The only patient (case 4 ) who had left heart catheterisation had left ventricular pressures of $75 / 15 \mathrm{mmHg}$, and a right atrial mean of

Table 3 Some presenting features in patients with heart disease

\begin{tabular}{|c|c|c|c|c|c|c|c|c|c|}
\hline Case No. & Age $(y)$ & Sex & Occupation & $\begin{array}{l}\text { Duration before } \\
\text { hospital }\end{array}$ & Headache & Fever & Itching & Rash & Chest pain \\
\hline 1 & 15 & $\mathrm{M}$ & Student & $5 \mathrm{mth}$ & 0 & + & + & + & 0 \\
\hline 2 & 13 & $\mathrm{M}$ & , & 3 wk & 0 & + & 0 & 0 & 0 \\
\hline 3 & 18 & $\mathbf{M}$ & " & $4 \mathrm{mth}$ & + & + & + & + & 0 \\
\hline 4 & 12 & $M$ & & $6 \mathrm{mth}$ & 0 & + & + & 0 & 0 \\
\hline 5 & 18 & $\mathbf{M}$ & Plumber & $7 \mathrm{~d}$ & + & + & 0 & 0 & + \\
\hline 6 & 7 & $\mathrm{M}$ & Student & $1 \mathrm{mth}$ & 0 & + & + & 0 & 0 \\
\hline 7 & 10 & $M$ & , & $2 \mathrm{~d}$ & + & + & 0 & 0 & 0 \\
\hline 8 & 6 & $\mathbf{M}$ & ", & $10 \mathrm{~d}$ & 0 & + & + & + & 0 \\
\hline 9 & 13 & $\mathrm{M}$ & ", & $4 \mathrm{mth}$ & 0 & + & + & + & 0 \\
\hline 10 & 8 & $\mathrm{~F}$ & ", & $6 \mathrm{mth}$ & + & + & + & 0 & 0 \\
\hline 11 & 14 & $\mathbf{M}$ & " & $4 \mathrm{mth}$ & 0 & + & 0 & 0 & 0 \\
\hline 12 & 13 & M & , & $6 \mathrm{mth}$ & 0 & + & + & 0 & 0 \\
\hline 13 & 16 & $\mathrm{M}$ & $"$ & $2 \frac{1}{2} \mathrm{mth}$ & 0 & + & + & + & + \\
\hline
\end{tabular}

TR, tricuspid: egurgitation; $P R$, pulmonary regurgitation; $M R$, mitral regurgitation; *, microfilaria noticed in conjunctiva. 


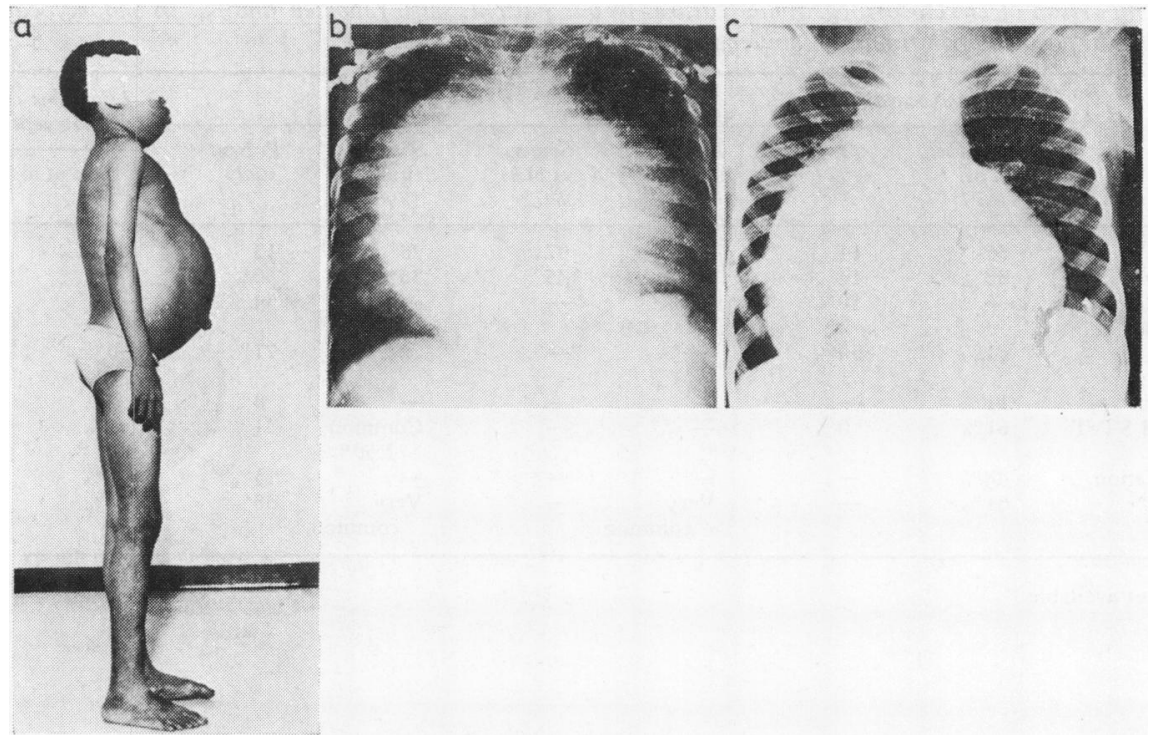

Fig. 1 Photograph, venous angiogram, and chest $\mathrm{x}$-ray in case 4. (a) Gross ascites without leg oedema, grossly puffy face, and proptosis (covered). (b) Venous angiogram shows pericardial effusion: $500 \mathrm{ml}$ of transudate was removed. (c) Chest radiograph after pericardiocentesis shows cardiomegaly with grossly dilated right atrium, prominent right ventricular outflow tract, and relatively oligaemic and clear lungs. Cardiac catheterisation confirmed the grossly dilated right atrium, right atrial mean pressure, $35 \mathrm{mmHg}$, " $v$ " wave of $40 \mathrm{mmHg}$, left ventricular pressure $75 / 15 \mathrm{mmHg}$ and aortic pressure, $=75 / 55$ (mean 64) $\mathrm{mmHg}$. A Cournand catheter could not be manipulated into the right ventricle from the grossly dilated right atrium.

$35 \mathrm{mmHg}$, with a "V" wave of $40 \mathrm{mmHg}$.

One of these eight patients (case 1) had two episodes of cerebral embolism during follow-up, with loss of consciousness, localising neurological findings, and reversible abnormal electroencephalographic changes. He recovered completely from both episodes. Three died (one at home). Necropsy was performed in one of the two (case 8) dying in hospital. The heart weighed $197 \mathrm{~g}$, and there was a moderate degree of fibrinous pericarditis (Fig. 4a).
The right atrium and right atrial appendage were dilated and almost completely filled by a large antemorterm thrombus (Fig. 4b); the tricuspid valve ring was dilated, but the leaflets of the tricuspid valve were normal; the right ventricular apex, the inflow tract, and the outflow tract up to the insertion of the pulmonary cusps, as well as the bases of the papillary muscles showed thick endocardial fibrous tissue (Fig. 4b). IThis endocardial thickening also affected the left ventricular apex and papillary

\begin{tabular}{|c|c|c|c|c|c|c|c|c|c|}
\hline Puffy face & Proptosis & Leg oedema & Ascites & $\begin{array}{l}\text { Pulsation in } \\
\text { pulmonary } \\
\text { area }\end{array}$ & $\begin{array}{l}\text { Valvular regur- } \\
\text { gitation }\end{array}$ & $\begin{array}{l}\text { Total } \\
\text { eosinophil } \\
\text { count } / \mathrm{mm}^{3}\end{array}$ & $\begin{array}{l}\text { White blood } \\
\text { cell count / } \\
\mathrm{mm}^{3}\end{array}$ & Microfilaria & $\begin{array}{l}\text { Chronic features of } \\
\text { endomyocardial } \\
\text { fibrosis }\end{array}$ \\
\hline+ & + & 0 & 0 & + & TR & 3600 & 6100 & 0 & + \\
\hline+ & 0 & 0 & 0 & + & TR & 9100 & 14800 & 0 & + \\
\hline+ & + & + & + & 0 & TR and $P R$ & 9600 & 15800 & $0^{\star}$ & + \\
\hline+ & 0 & 0 & + & 0 & TR & 3480 & 7250 & $0 \star$ & + \\
\hline j & 0 & 0 & 0 & + & TR & 3120 & 8000 & 0 & + \\
\hline+ & 0 & + & + & + & TR and $M R$ & 3240 & 8920 & 0 & $\stackrel{T}{-}$ \\
\hline 0 & 0 & 0 & 0 & + & 0 & 5220 & 6880 & 0 & - \\
\hline+ & 0 & + & + & + & TR & 3040 & 13000 & + & + \\
\hline+ & 0 & 0 & 0 & 0 & TR & 3380 & 5900 & 0 & $\underline{-}$ \\
\hline+ & + & 0 & + & 0 & TR & 3020 & 11800 & + & - \\
\hline+ & 0 & 0 & + & + & TR & 5340 & 9520 & + & + \\
\hline+ & 0 & 0 & 0 & + & TR & 3600 & 7000 & $+\star$ & + \\
\hline+ & 0 & 0 & 0 & 0 & MR & 4000 & 8700 & + & $\stackrel{T}{-}$ \\
\hline
\end{tabular}


Table 4 Comparison of electrocardiographic features of our patients with reported findings in endomyocardial fibrosis and in idiopathic congestive cardiomyopathy in children

\begin{tabular}{|c|c|c|c|c|c|c|c|}
\hline & \multicolumn{6}{|c|}{ Endomyocardial fibrosis } & \multirow{3}{*}{$\begin{array}{l}\text { Idiopathic congestive } \\
\text { cardiomyopathy (children) } \\
\text { Antia et al. }{ }^{22} 1969\end{array}$} \\
\hline & \multirow{2}{*}{$\begin{array}{l}\text { D'Arbela } \\
\text { et al. }{ }^{19} \\
1974\end{array}$} & \multirow{2}{*}{$\begin{array}{l}\text { Antia et al. }{ }^{9} \\
1974\end{array}$} & \multirow{2}{*}{$\begin{array}{l}\text { Abrahams } 23 \\
1961\end{array}$} & \multirow{2}{*}{$\begin{array}{l}\text { Somers } \\
\text { et al. }{ }^{21} \\
1972\end{array}$} & \multirow{2}{*}{$\begin{array}{l}\text { Somers } \\
\text { et al. }{ }^{20} \\
1.968\end{array}$} & \multirow{2}{*}{$\begin{array}{l}\text { Present } \\
\text { study }\end{array}$} & \\
\hline & & & & & & & \\
\hline No. of patients & 56 & 14 & $?$ & 97 & 28 & 13 & 13 \\
\hline Atrial arrhythmias & $32^{\circ} \%$ & $14 \%$ & $50^{\circ}$ & $35 \%$ & $36 \%$ & $30 \%$ & $0 \%$ \\
\hline Right atrial enlargement & - & $50^{\circ}$ & - & - & - & $54 \%$ & - \\
\hline $\begin{array}{l}\text { Right ventricular } \\
\text { hypertrophy }\end{array}$ & $61^{\circ}$ & $50^{\circ}$ & & & & & \\
\hline Left ventricular & $01 \%$ & $50 \%$ & - & - & $72 " \prime \prime$ & $77^{\circ}$ & $0^{\prime \prime}$ \\
\hline hypertrophy & $11^{\circ} \circ$ & - & - & - & - & $8^{\circ}$ & $0 \%$ \\
\hline $\begin{array}{l}\text { Subendocardial ST-T } \\
\text { changes }\end{array}$ & $61 \%$ & $0^{\circ}$ & - & - & $\begin{array}{c}\text { Common } \\
? 50^{\circ}\end{array}$ & $31 \%$ & $0^{\prime \prime \prime}$ \\
\hline Right axis deviation & $48^{\circ}$ & 一 & - & - & - & $15 \%$ & $00_{0}$ \\
\hline Low voltage & $61{ }^{\circ} \circ$ & - & $\begin{array}{l}\text { Very } \\
\text { common }\end{array}$ & - & $\begin{array}{l}\text { Very } \\
\text { common }\end{array}$ & $38 \%$ & $0^{\circ}$ \\
\hline
\end{tabular}

$-=$ Figure not available.

(a)

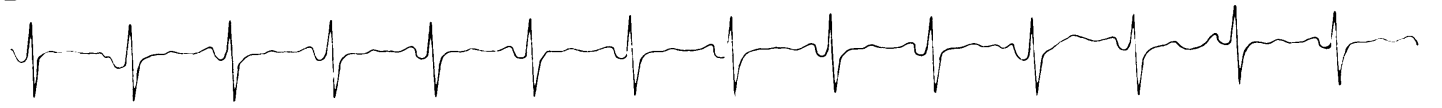

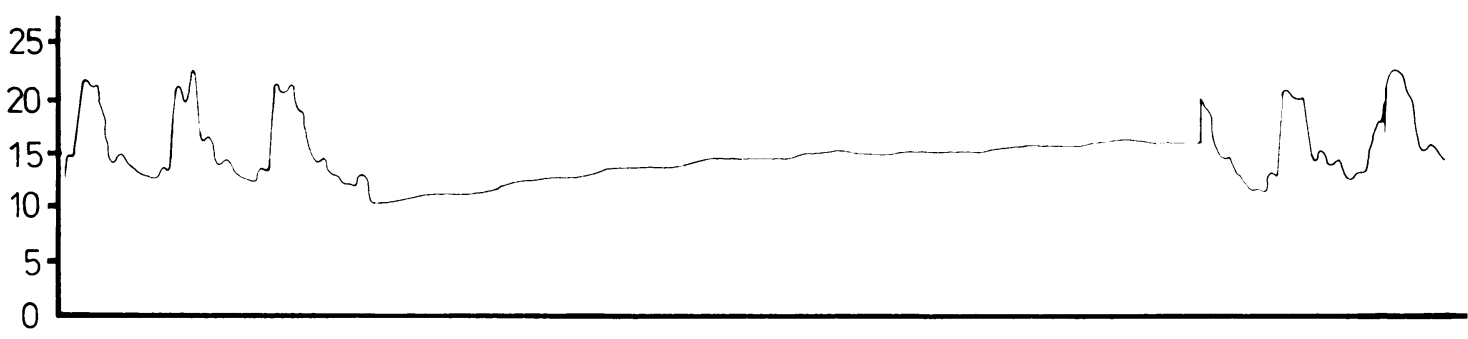

(b)

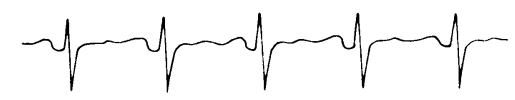

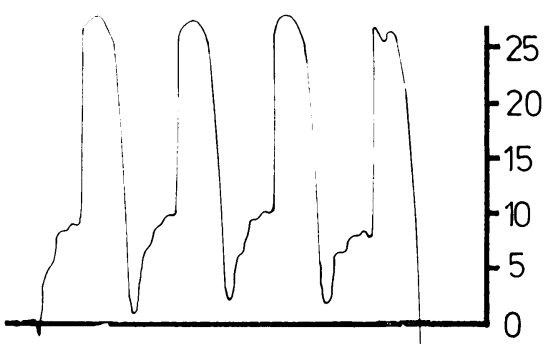

(C)

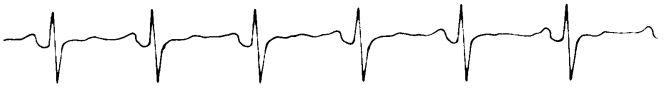

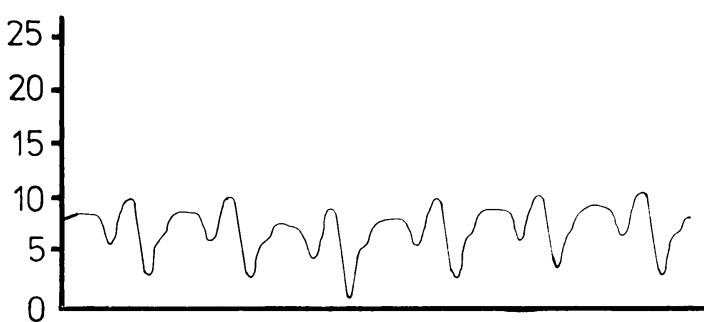

Fig. 2 Right sided pressures in case 5 recorded after successful treatment of heart failure. (a) Pulmonary artery systolic pressure $22 / 11 \mathrm{mmHg}$ (mean pressure shown in centre of trace). (b) Right ventricular pressure contour showing $a$ dip and plateau. (c) Right atrial pressure, " $a$ ", $9 \mathrm{mmHg}$, " $v$ ", $10 \mathrm{mmHg}$. Right atrial pressure contour was " $\mathrm{m}$ " shaped with a deep " $y$ " trough. Mean wedge pressure (not shown) was $11 \mathrm{mmHg}$. 


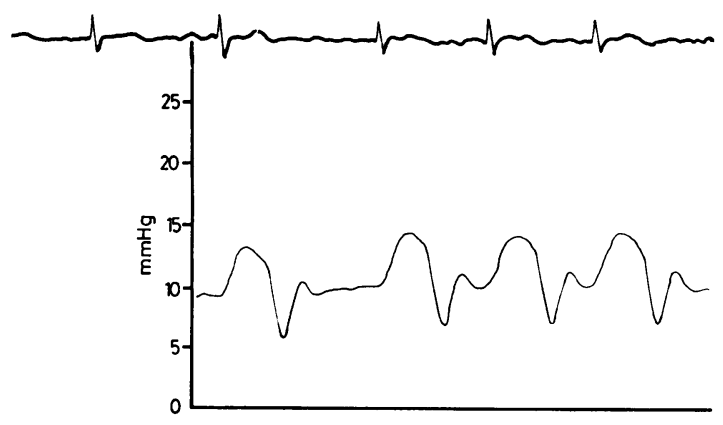

Fig. 3 Right atrial pressure in case 3 who was in atrial fibrillation, showing a regurgitant " $V$ " wave. muscles at their base, but the inflow and outflow tracts were spared (Fig. 4c). The left ventricle and left atrium were not dilated and the mitral and aortic valves were normal. The right ventricular endocardium was replaced by a thick layer of dense hyalinised vascular fibrous tissue which also involved the inner third of the myocardium and the subpericardial zones severely, but the rest of the myocardium much less so (Fig. 5a, b, and c). The pericardium was replaced by granulation tissue with loose collagen fibres and dilated blood vessels, and was infiltrated by mononuclear cells and a few eosinophils (Fig. 5c and d).
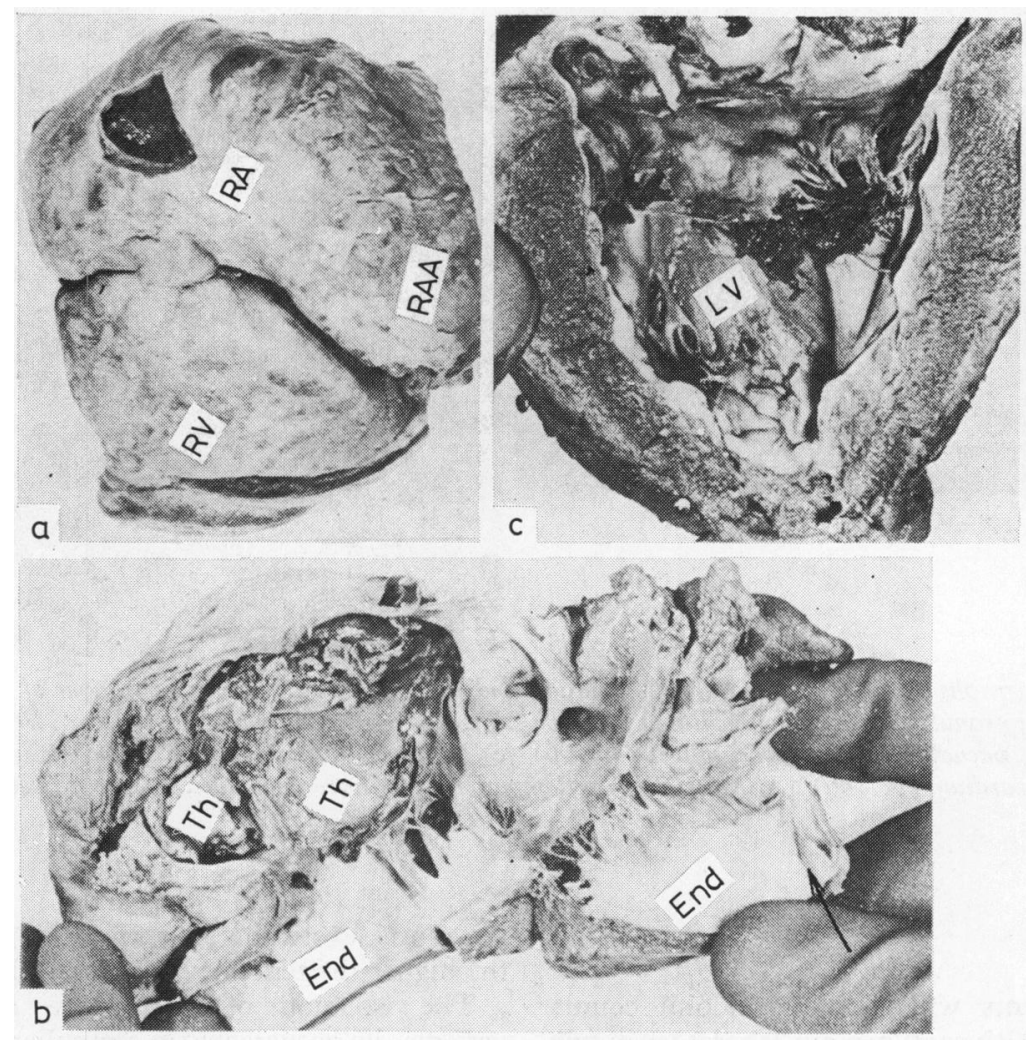

Fig. 4 The heart in case 8. (a) Photograph of the whole heart shows a moderate degree of fibrinous pericarditis and a dilated right atrium $(R A)$ and right atrial appendage (RAA). (b) Section through the right heart shows a dilated right atrium almost completely filled by antemorterm thrombus (Th) and severe thickening of the endocardium of the right ventricle, including the inflow tract and the outflow tract up to, but sparing, the pulmonary cusps (arrow). This thickening is most severe at the apex and bases of the papillary muscles. (c) The left ventricle shows endocardial thickening in the inflow tract and apex, but the outflow tract is spared. 

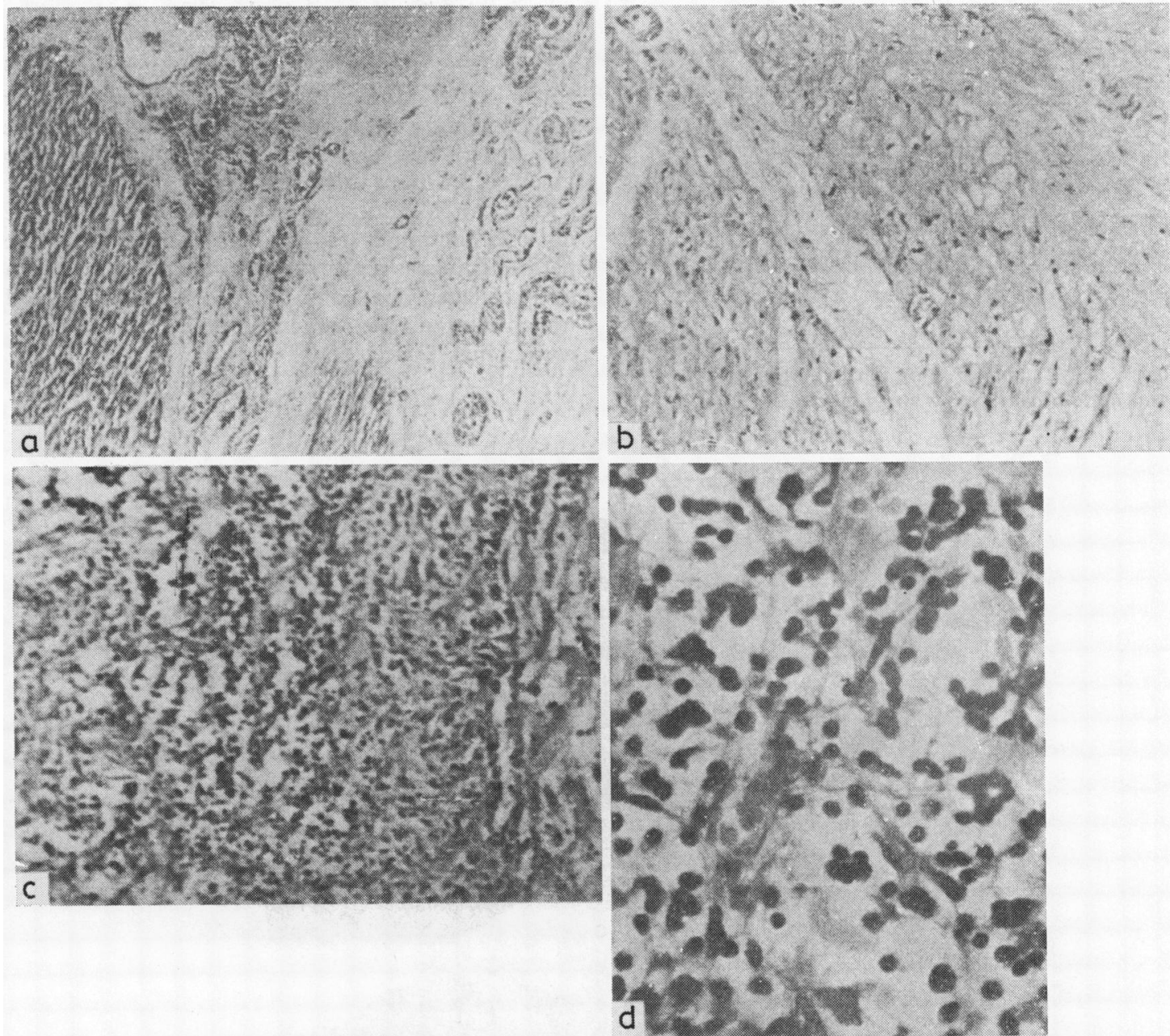

Fig. 5 Photomicrographs showing pericardial inflammation and endomyocardial fibrosis. (a) Layer of endocardial and endomyocardial granulation tissue with dilated blood vessels and chronic inflammatory cells $(\times 100)$. (b) Myocardial fibrosis, vacuolation, and myocytolysis $(\times 100)$. (c) Moderately heavy degree of chronic inflammatory reaction in the pericardium $(\times 100)$. (d) Most of the inflammatory cells were mononuclear cells and eosinophils $(\times 400)$.

\section{Discussion}

Of the 44 patients with total eosinophil counts greater than the 97 th centile in our laboratory in two years, 29.5 per cent had recently developed myocardial disease. The highest eosinophil counts, 9600 and $9100 \mathrm{~mm}^{3}$, respectively, recorded in our laboratory during this period were in two such patients. Johny and Ananthachari ${ }^{24}$ studied electrocardiographic abnormalities associated with tropical eosinophilia and showed that these were more frequent at higher eosinophil levels. It appears that the more severe the allergic eosinophilic response, the higher the tendency to myocardial damage.

The isolation of microfilaria loa-loa in five patients, its occurrence on a number of occasions in the cornea of two more, the reversal of eosinophilia with diethylcarbamazine in all cases, and the clinical $\stackrel{\mathscr{P}}{\rightarrow}$ findings of afternoon fever, itching, rash, and periorbital swelling appear to implicate microfilariasis as the cause of the raised total eosinophil counts in these patients. The cardiac lesion appeared in general better tolerated by them than by patients with non-eosinophil associated heart disease, 西

$\stackrel{+}{+}$


possibly because right-sided cardiac damage was preponderant.

The clinical diagnosis of advanced cases of rightsided (and sometimes biventricular) endomyocardial fibrosis is usually relatively easy since most of the patients show evidence of cardiac constriction. The differentiation from constrictive pericarditis rests on the additional presence of atrioventricular valve regurgitation, sometimes of a large pericardial effusion, and sometimes of recurrent pulmonary or systemic emboli. ${ }^{23-26}$ Those of our patients who were catheterised showed findings suggestive of constriction and/or tricuspid regurgitation though the data were limited, but all who developed constriction clinically also had clinical evidence of tricuspid regurgitation. A large pericardial effusion occurred in one patient, and another had recurrent cerebral embolism. In addition the disproportionate enlargement of the right atrium on chest radiography, confirmed at cardiac catheterisation in some, together with the close similarities of the electrocardiograms of these patients to those previously described in endomyocardial fibrosis lend further support to that being the diagnosis in these patients.

In a clinical study of 102 Nigerian patients in whom endomyocardial fibrosis was diagnosed by angiocardiography, haemodynamic studi $s$, and necropsy, isolated left ventricular disease occurred in 4 per cent, and right ventricular disease and biventricular disease dominated. ${ }^{26}$ The same study also recorded that the presence of associated right heart disease always tended to mask the features of left ventricular disease, regardless of its severity, and that patients with biventricular endomyocardial fibrosis presented clinically as if they had isolated right-sided disease. Thus the evolution over a long period of time of clinical features indistinguishable from those of chronic right-sided endomyocardial fibrosis by 73 per cent of our patients seen early in the course of their heart disease and selected only because the total eosinophil count was greater than the 97th centile, is consistent with the theory associating endomyocardial fibrosis with eosinophilia. The diagnosis was confirmed macroscopically and by histopathology in the only patient on whom necropsy was performed (Fig. 4 and 5). This patient (case 8), a 6-year-old boy, was unique among African patients with endomyocardial fibrosis in that he was born in our hospital, and was a regular attendant at the infant and child welfare clinic so that his childhood diseases were known. The onset of his cardiac symptoms, 10 days before admission, as well as the progression of his illness until death $25 \frac{1}{2}$ months later, were well observed and documented. Microfilaria loa-loa was found by the Knott's concentration technique, and his raised eosinophil count was brought back to normal by diethylcarbamazine, about 24 months before his death from heart disease, when endomyocardial fibrosis was finally diagnosed.

The following conclusions appear reasonable from our observations: (1) parasite-induced eosinophilia of a very severe degree in Africa is frequently associated with heart disease; (2) the associated heart disease frequently develops clinical features typical of chronic endomyocardial fibrosis many months after the eosinophilia has returned to normal; (3) on clinical grounds, limited cardiac catheterisation findings, and on macroscopical and histopathological findings on the only patient who came to necropsy this associated heart disease is probably endomyocardial fibrosis; and (4) microfilariasis was the cause of eosinophilia among these patients. These conclusions support previous suggestions that chronic African endomyocardial fibrosis is the burn-out phase of an eosinophilic heart disease. ${ }^{1}$ Well-designed efforts to establish an association between endomyocardial fibrosis and eosinophilia in the past ${ }^{15-17}$ were frustrated possibly because it was usually the burnt-out phase of the disease that was studied, since early endomyocardial fibrosis is not readily recognised. The mechanism by which eosinophilia damages the endocardium is not known.

We acknowledge the help and advice of Professor AU Antia of University College Hospital, Ibadan.

\section{References}

1 Roberts WC, Liegler DG, Carbone PP. Endomyocardial disease and eosinophilia. A clinical and pathologic spectrum. Am F Med 1969; 46: 28-42.

2 Libanoff AJ, McMahon NJ. Eosinophilia and endomyocardial fibrosis. Am $\mathcal{f}$ Cardiol 1976; 37: 438-41.

3 Bayley EC, Lindberg, DON, Baggenstoss AH. Loeffler's syndrome: report of a case with pathologic examination of the lungs. Arch Pathol 1945; 40: 37681.

4 Gruber GB, Gamper E. Uber gehirnvveränderungen bei menschlicher Trichinose. Verhandlungen der Deutschen pathologischen Gesellschaft 1927; 22: 21921.

5 Andy JJ, O'Connell JP, Daddario RC, Roberts WC. Trichinosis causing extensive ventricular mural endocarditis with superimposed thrombosis. Evidence that severe eosinophilia damages endocardium. Am F Med 1977; 63: 824-9.

6 Gerbaux A, Garin JP, Lenègre J. Cardiopathie et filariose. Bull Soc Med Paris 1957; 73: 873-87.

7 Davies JNP. Endomyocardial fibrosis in Uganda. Cent Afr F Med 1965; 2: 323-8.

8 Davies JNP. The heart of Africa. Cardiac pathology in the population of Uganda. Lab Invest 1961; 10: 205-15. 
9 Antia AU, Effiong CE, Dawodu AH. The pattern of acquired heart disease in Nigerian children. $A f r \mathcal{F}$ Med Sci 1972; 3: 1-12.

10 Brockington IF, Olsen EGJ. Löffler's endocarditis and Davies' endomyocardial fibrosis. Am Heart $\mathcal{F}$ 1973; 85: 308-22.

11 Brockington IF, Olsen EGJ, Goodwin JF. Endomyocardial fibrosis in Europeans resident in tropical Africa. Lancet 1967; i: 583-8.

12 Baltzenschlager A, Reville P, Finker L. La myoendocardite fibreus parietale de l'adulte. Ann Anat Pathol (Paris) 1961; 6: 111-21.

13 Giraud G, Latour H, Puech P, Olivier G, Hertault J. Cardiopathie filarienn étude hémodynamique. Montpellier Medical 1959; 55: 44-53.

14 Gardner-Thorpe C, Harriman DGF, Parsons M, Rudge P. Löffler's eosinophilic endocarditis with Balint's syndrome (optic ataxia and paralysis of visual fixation). Qf Med 1971; 40: 249-60.

15 Ive FA, Willis AJP, Ikeme AC, Brockington IF. Endomyocardial fibrosis and filariasis. $Q \mathcal{F} \mathrm{Med} 1967$; 36: 495-516.

16 Brockington IF. Endomyocardial fibrosis, filariasis and eosinophilia. In: Shaper AG, Hutt MSR, Fejfar Z, eds. Cardiovascular disease in the tropics. London: British Medical Association, 1974: 42-5.

17 Patel AK, D'Arbela PG, Somers K. Endomyocardial fibrosis and eosinophilia. Br Heart $\mathcal{F}$ 1977; 39: 238-41.

18 Brink AJ, Weber HW. Fibroplastic parietal endocarditis with eosinophilia. $A m \mathcal{F}$ Med 1963; 34: 5270.
19 D'Arbela PG, Patel AK, Somers K. Electrocardiographic features of endomyocardial fibrosis. In: Kamunvi, Ojiambo, Bajusz, eds. Myocardiology in Africa. Nairobi, Dares-Salaam, Kampala: East African Literature Bureau, 1974: 41-8.

20 Somers K, Brenton DP, Sood NK. Clinical features of endomyocardial fibrosis of the right ventricle. Br Heart f 1968; 30: 309-21.

21 Somers K, Gunstone RF, Patel AK, D'Arbela PG. Atrial arrhythmias in endomyocardial fibrosis. Cardiology 1972; 57: 369-73.

22 Antia AU, Cockshott WP, Thorpe GJ. Idiopathic cardiomegaly in Nigerian children. Br Heart $\mathcal{F} 1969$; 31: 178-83.

23 Abrahams DG. Endomyocardial fibrosis of the right ventricle. $Q$ f Med 1961; 31: 1-20.

24 Johny KV, Ananthachari MD. Cardiovascular changes in tropical eosinophilia. Am Heart $\mathcal{F}$ 1963; 69: 591-8.

25 World Health Organisation: Cardiomyopathies. Bull WHO 1965; 33: 257-65.

26 Fowler JM, Somers K. Left-ventricular endomyocardial fibrosis and mitral incompetence. A new syndrome. Lancet 1968; i: 227-8.

27 Ikeme AC. The diagnosis of endomyocardial fibrosis. Afr 'f Med Sci 1972; 3: 327-33.

Requests for reprints to Dr J J Andy, Department of Medicine and Mental Health, Faculty of Health Sciences, University of Ife, Ile-Ife, Nigeria. 